\title{
THE ROLE OF E-SERVICE QUALITY TO CUSTOMER SATISFACTION AND LOYALTY
}

\author{
Jacoby R. Wyer, Thomas M. Mells
}

\begin{abstract}
The existence of the internet is followed by the development of various advanced technologies such as smartphones. A smartphone is a smart phone that is equipped with various convenience features for its users. Many aspects of life are affected by the development of the internet, one of which is consumer behavior. Consumer behavior is dynamic, meaning that consumer behavior is always changing and moving all the time, therefore when the Internet and technology continue to develop, consumer behavior also changes, including in terms of shopping. Customer satisfaction and loyalty depends on the quality of service provided by the company, in the online market we are more familiar with e-service quality is a new version of service quality that was developed to evaluate a service provided on the internet network. This study will examine the effect of e-service quality on customer satisfaction and loyalty by involving 276 respondents who frequently shop online. The analytical tool used is path analysis. From the findings of the study mentioned that e-service quality has a significant influence on customer satisfaction but e-service quality does not have a significant effect on customer loyalty.
\end{abstract}

Keywords: e-service quality, customer satisfaction, loyalty

Introduction

Service quality is one of the important issues discussed by the company as an effort to maintain the existence of its business in the midst of existing competition. In today's digital era, information technology takes a very important role in aspects of human life because it makes it easier to do various activities, including business activities. Business companies must be able to adapt, if initially the company focused on product quality and how to provide direct service with quality, now the company is confronted with the fact that to win in the midst of competition, companies must provide online or electronic media, which of course must also be quality. Measuring the quality of service from electronic media is one of the focuses of the company in the digital age.

The development of the internet has brought many changes in aspects of human life. The internet makes things easier and faster, the development of the internet which is also balanced with the development of technology makes things in human life faster and easier. Online shopping is a popular trend nowadays, because consumers do not need to bother going to the store to buy the desired item, but enough to open an online shopping site and search for desired items using a smartphone or computer connected to the internet. Many aspects of life are affected by the development of the internet, one of which is consumer behavior. Consumer behavior is dynamic, meaning that consumer behavior is always changing and moving all the time, therefore when the internet and technology continue to develop, consumer behavior also changes, including in terms of shopping. 
This study only examined electronic services for satisfaction and their impact on loyalty. There are still many other factors that can affect consumer loyalty, such as web experience, and electronic word of mouth, so for future researchers, it is expected to develop this research, add the number of respondents, and examine other factors not examined in this study.

\section{References}

Ailawadi, K.L., Neslin, S.A. and Gedenk, K. (2001), "Pursuing the value-consciousconsumer: store brands versus national brand promotions", Journal of Marketing, Vol. 65 (January), pp. 71-89.

Anderson, E. and Sullivan M.. (1993), "The antecedents and consequences of customersatisfaction for firms," Marketing Science, Vol. 12 pp. 125-143.

Anderson, E., Fornell, C. and Lehman, D. (1994), "Customer satisfaction, market share, and profitability: findings from Sweden", Journal of Marketing, Vol. 58 pp.53-66

Back, K., Parks, S.C. (2003). A brand loyalty model involving cognitive, affective and conative brand loyalty and customer satisfaction. Journal of hospitality and tourism research, Vol.27 (4), pp.419-435

Ball, S.J, Auh, S. and Smalley, K. (2004). Customer relationship dynamics: service quality and customer loyalty in the context of varying levels of customer expertise and switching costs. Journal of the Academy of Marketing Science, Vol. 33, pp. 169-83

Bloemer, J.M.M. and Kasper, H.D.P. (1994), "The impact of satisfaction on brand loyalty: Urging on classifying satisfaction and brand loyalty", Journal of Consumer Satisfaction, Dissatisfaction and Complaining Behavior, Vol. 7, pp. 152-160.

Bloemer, J.M.M. and Kasper, H.D.P. (1994), "The impact of satisfaction on brand loyalty: Urging on classifying satisfaction and brand loyalty", Journal of Consumer Satisfaction, Dissatisfaction and Complaining Behavior, Vol. 7, pp. 152-160.

Coyne, K. (1989), "Beyond service fads - meaningful strategies for the real world", Sloan Management Review, Vol. 30 (4), pp.69-76.

Chaudhuri, A. and Holbrook, M.B. (2001), "The chain of effects from brand trust and brand affect to brand performance: The role of brand loyalty", Journal of Marketing, Vol. 65 (2), pp. 81-94.

Cronbach, L.J. (1951), "Coefficient alpha and the internal structure of test", Psichometrica, Vol. 16 (October), pp. 297-334.

Dacin, P.A. and Smith D.C. (1994), "The effect of brand portfolio characteristics on consumer evaluations of brand extensions", Journal of Marketing Research, Vol. 31 (May), pp. 229-242.

Darmawan, Didit., Rahayu Mardikaningsih, Surjo Hadi. (2017). The Effect of Service Quality, Customer Satisfaction and Corporate Image on Customer Loyalty in the Banking Sector in Indonesia, Journal of Business and Management International Organization of Scientific Research, Vol.19 Issue.11, 46-51 
Darmawan, Didit. (2018). The Effect of Brand Experience on Brand Trust and Brand Loyalty, Journal of Translitera, Vol 7. No 2 September, 13-24

Fornell, C. (1992), "A national customer satisfaction barometer: the Swedish experience," Journal of Marketing, Vol. 56 (1), pp. 6-21.

Getty, J.M. and Thompson, K.N. (1994), “The relationship between quality, satisfaction and recommending behaviour in lodging decisions", Journal of Hospitality \& Leisure Marketing, Vol. 2 (3), pp. 3-22.

Gremler, D. and Brown, S. (1999), "The loyalty ripple effect: appreciating the full value of customers", International Journal of Service Industry, Management, Vol. 10 (3), pp. 271-91.

Fornell, C. (1992), "A national customer satisfaction barometer: the Swedish experience," Journal of Marketing, Vol. 56 (1), pp. 6-21.

Getty, J.M. and Thompson, K.N. (1994), "The relationship between quality, satisfaction and recommending behaviour in lodging decisions", Journal of Hospitality \& Leisure Marketing, Vol. 2 (3), pp. 3-22.

Gremler, D. and Brown, S. (1999), "The loyalty ripple effect: appreciating the full value of customers”, International Journal of Service Industry, Management, Vol. 10 (3), pp. 271-91.

Kasper, H. (1988), "On problem perception, dissatisfaction and brand loyalty", Journal of Economic Psychology, Vol. 9, pp.387-97.

Keller, K.L. (1993), “Conceptualizing, measuring, and managing customer-based brand equity”, Journal of Marketing, Vol. 57 (January), pp.1-22.

Klink, R. and Smith, D. (2001), "Threats to the external validity of brand extensions research", Journal of Marketing Research, Vol. 38 (August), pp. 326-335.

Masitoh, Dewi, Didit Darmawan. Ella Anastasya Sinambela. (2017). The Effect of Service Quality and Trust on Customer Loyalty of Warung Apung Rahmawati of Mojokerto Branch, Journal of Agrimas, Vol.1 No.2 December, 107-114

Mellens, M.; Dekimpe, M.G. and Steenkamp, J.B.E.B. (1996), "A review of brand-loyalty measures in marketing", Tijdschrift voor Economie en Management, Vol. 41 (4), pp. 507-533.

Morgan, R.M. and Hunt, S.D. (1994), "The commitment-trust theory of relationship marketing”, Journal of Marketing, Vol. 58 (3), pp. 20-38.

Newman, J.W. and Werbel, R.A. (1973), "Multivariate analysis of brand loyalty for major household appliances", Journal of Marketing Research, Vol. 10 (4), pp. 404-409.

Solomon, M.R. (1992), Consumer Behavior: Buying, Having and Being, Allyn and Bacon, Needham Heights, MA.

Srinivasan, S., Anderson, R. and Ponnavolu, K. (2002), "Customer loyalty in e-commerce: an examination of its antecedents and consequences", Journal of Retailing, Vol. 78 (1), pp.41-50.

Zeithaml, V., Parasuraman, A. and Berry, L. (1990), Delivering Quality Service, The Free Press, New York, NY.

Zeithaml, V., Berry, L. and Parasuraman, A. (1996), "The behavioral consequences of service quality", Journal of Marketing, Vol. 60, pp. 31-46. 